\title{
Meeting the demand: geothermal heat supply rates for an urban quarter in Germany
}

\author{
Carolin Tissen ${ }^{1 *} \mathbb{0}$, Kathrin Menberg ${ }^{1}$, Peter Bayer $^{2}$ and Philipp Blum ${ }^{1}$
}

${ }^{*}$ Correspondence: carolin.tissen@kit.edu ${ }^{1}$ Institute of Applied Geosciences (AGW), Karlsruhe Institute of Technology (KIT), Kaiserstraße 12,

76131 Karlsruhe, Germany Full list of author information is available at the end of the article

\begin{abstract}
Thermal energy for space heating and for domestic hot water use represents about a third of the overall energy demand in Germany. An alternative to non-renewable energy-based heat supply is the implementation of closed and open shallow geothermal systems, such as horizontal ground source heat pump systems, vertical ground source heat pump (vGSHP) systems and groundwater heat pump systems. Based on existing regulations and local hydrogeological conditions, the optimal site-specific system for heat supply has to be identified. In the presented technical feasibility study, various analytical solutions are tested for an urban quarter before and after building refurbishment. Geothermal heat supply rates are evaluated by providing information on the optimal system and the specific shortcomings. Our results show that standard vGSHP systems are even applicable in older and non-refurbished residential areas with a high heat demand using a borehole heat exchanger with a length of $100 \mathrm{~m}$ or in conjunction with multiple boreholes. After refurbishment, all studied shallow geothermal systems are able to cover the lowered heat demand. The presented analysis also demonstrates that ideally, various technological variants of geothermal systems should be evaluated for finding the optimal solution for existing, refurbished and newly developed residential areas.
\end{abstract}

Keywords: Ground source heat pump (GSHP), Groundwater heat pump (GWHP), Borehole heat exchanger (BHE), Heat demand, Refurbishment, Geothermal potential, GIS

\section{Introduction}

In 2016, the annual energy consumption for space heating and domestic hot water (DHW) in Germany was 2987 PJ, which corresponded to approximately a third of Germany's total energy consumption. The main energy sources are still coal, oil and gas, which emit large amounts of $\mathrm{CO}_{2}$ and contribute to global climate warming. For space heating and DHW, only $15 \%$ of the energy consumption was provided by renewable energies (BMWi 2018). Among this 15\% portion, shallow geothermal energy systems are particularly appealing, since they are continuously available. Lund and Boyd (2016) showed that 149.1 million tonnes of $\mathrm{CO}_{2}$ could be annually saved by the direct utilization of geothermal energy. Bayer et al. (2012) estimated that the potential heat supply by ground source heat pump (GSHP) systems for 19 European countries is 100,000 TJ, corresponding to $\mathrm{CO}_{2}$ savings of 3.7 million tonnes. Therefore, there is a great potential for geothermal energy systems to lower current greenhouse gas emissions.

(c) The Author(s) 2019. This article is distributed under the terms of the Creative Commons Attribution 4.0 International License (http://creativecommons.org/licenses/by/4.0/), which permits unrestricted use, distribution, and reproduction in any medium, provided you give appropriate credit to the original author(s) and the source, provide a link to the Creative Commons license, and indicate if changes were made. 
Shallow geothermal systems, which can be classified into closed and open systems, enable the direct use of geothermal energy. In closed systems, a synthetic heat carrier fluid is circulated in tubes that are installed in the ground for heat exchange. Open systems utilize wells to access groundwater as a heat carrier. In both variants, heat pumps are often employed for extracting heat and supplying heating applications. Closed-loop systems include horizontal (hGSHP) and vertical ground source heat pump (vGSHP) systems. In general, the ability of these systems to provide heating and/or cooling is described as the geothermal potential, for which multiple definitions and concepts exist. For example, Zhu et al. (2010) and Zhang et al. (2014) computed the theoretical geothermal potential as the heat content stored in a given volume of the subsurface for a given temperature reduction. According to Götzl et al. (2010), the potential of shallow geothermal energy is a combination of the technical potential, i.e., the energetic supply, and the applicability on part of energy consumers. A similar definition was given by Zhang et al. (2014) and Galgaro et al. (2015), who defined a ratio of the maximum amount of energy exchanged between the ground and vGSHP system to the heat or cooling demand. In our study, we follow the same concept and for a simplification, use the term "heat supply rate".

Depending on the type of system, the geothermal potential can be evaluated in different ways. To estimate the very shallow geothermal energy potential of hGSHP systems, Bertermann et al. (2014) included legal constraints, climatic parameters and soil textures. García-Gil et al. (2015) proposed a low temperature geothermal potential (LTGP) for open- and closed-loop systems. They estimated the LTGP of the saturated zone using a steady-state analytical solution for conductive and advective heat transfer in porous media and applying a line source model for the unsaturated zone. Bezelgues-Courtade et al. (2010) created a geothermal potential map by combining several criteria such as transmissivity, temperature and hydrochemistry in a geographical information system (GIS).

Previous studies typically focused on the potential of one type of geothermal system. Mostly, vGSHP systems were examined by, for example, Casasso and Sethi (2016), Noorollahi et al. (2017) and Ondreka et al. (2007). Until now, evaluations of the potential of hGSHP and GWHP systems have attracted less attention (Bertermann et al. 2015; Bezelgues-Courtade et al. 2010). Epting et al. (2013) and (2018) focus on the potential of the groundwater body in the city of Basel. For the city of Barcelona, García-Gil et al. (2015) contrasted the results for vGSHP and GWHP systems. Götzl et al. (2010) conducted a comparative analysis of hGSHP and vGSHP systems for Austria. So far, however, no study has examined all three types of systems on a common ground, and a detailed comparison of the systems' abilities to meet the heat demand of an urban quarter is still lacking. As the different technologies have different requirements, they are not equally suited. As a consequence, their geothermal potential will be different.

Many concepts of the geothermal potential refer to the actual heat (or cooling) demand of the study area, which is typically not exactly known. Though such data are often collected by the energy supplier, it is rarely publicly available. For this reason, the heat demand is often estimated based on various assumptions and limited available data, such as building footprint and year of construction. Various studies use settlement types to categorize buildings and link them to the height and floor area of typical buildings 
(Gemelli et al. 2011; Rivera et al. 2017; Schiel et al. 2016; Zhang et al. 2014). The estimation of Götzl et al. (2010) also included the year of construction and climatic conditions. Schiel et al. (2016) pointed out that the imprecise estimation of the heat demand causes a large error in the determination of the borehole heat exchanger length required to supply urban demand by means of geothermal systems. Thus, a more accurate assessment of the feasible geothermal supply rate requires more precise, i.e., measured, energy consumption data.

The actual heat demand of an urban quarter is largely determined by the age of the buildings, or more precisely the energy standard. Eicker et al. (2011) considered only modern buildings with a typical low energy consumption. Noorollahi et al. (2017) worked with the heating and cooling demand of a new building and extrapolated it to the whole of Iran. Schiel et al. (2016) obtained a wider range of values for their calculations of the heat demand of the city Ludwigsburg in Germany, as their study distinguished old and new buildings with different energy standards. Eicker et al. (2011) and Blum et al. (2011) noted that GSHP systems in Germany are typically installed in new, single-family buildings with a low heat demand, which are usually supplied with heat by two borehole heat exchangers (BHEs). However, as stated by De Carli et al. (2014) and Solomon (2017), it is more reasonable to plan geothermal systems for an entire quarter or city instead of focusing only on individual houses.

This technical feasibility study explores and compares the potential of the three major shallow geothermal technologies (hGSHP, vGSHP and GWHP) by a spatial analysis using ArcGIS and analytical solutions for estimating the heat supply rate. For this, existing regulations and local hydrogeological conditions are considered. In particular, we address the question whether the heat demand for space heating and domestic hot water (DHW) before and after the refurbishment of an urban quarter can be satisfied by one of these geothermal systems. For this purpose, we compute the heat supply rate that compares the geothermal potential of the three systems to the measured heat demand in an urban quarter of Karlsruhe, Germany.

\section{Materials and methods}

\section{Study site}

The study site is called "Rintheimer Feld" (RF), an urban quarter of $0.13 \mathrm{~km}^{2}$ in the eastern part of Karlsruhe, which is located in the south-west of Germany and in the northern part of the Upper Rhine Graben (Fig. 1). This study focuses on 31 multi-family houses providing living space for approximately 2500 inhabitants (Jank 2013). The area is characterized by wide green spaces with shrubbery and trees used for playgrounds and recreational purposes (Fig. 2). The houses are owned by the municipal real estate company called "Volkswohnung GmbH" and were built between the 1950s and 1970s (Fig. 2). Housing complexes of the post-war era dominate the northern part of the quarter, whereas the southern part contains high-rise buildings of the 1960s and 1970s. With the aim to reduce $\mathrm{CO}_{2}$ emissions and costs for heat supply, all buildings were refurbished in multiple stages between 1998 and 2014. The total costs of refurbishment amount to around 70 Mio. $€$. In this study, recently constructed buildings in the southern part are not considered, since the space for system installation and the heating area would change before and after refurbishment, and a direct comparison of the heat supply rate 


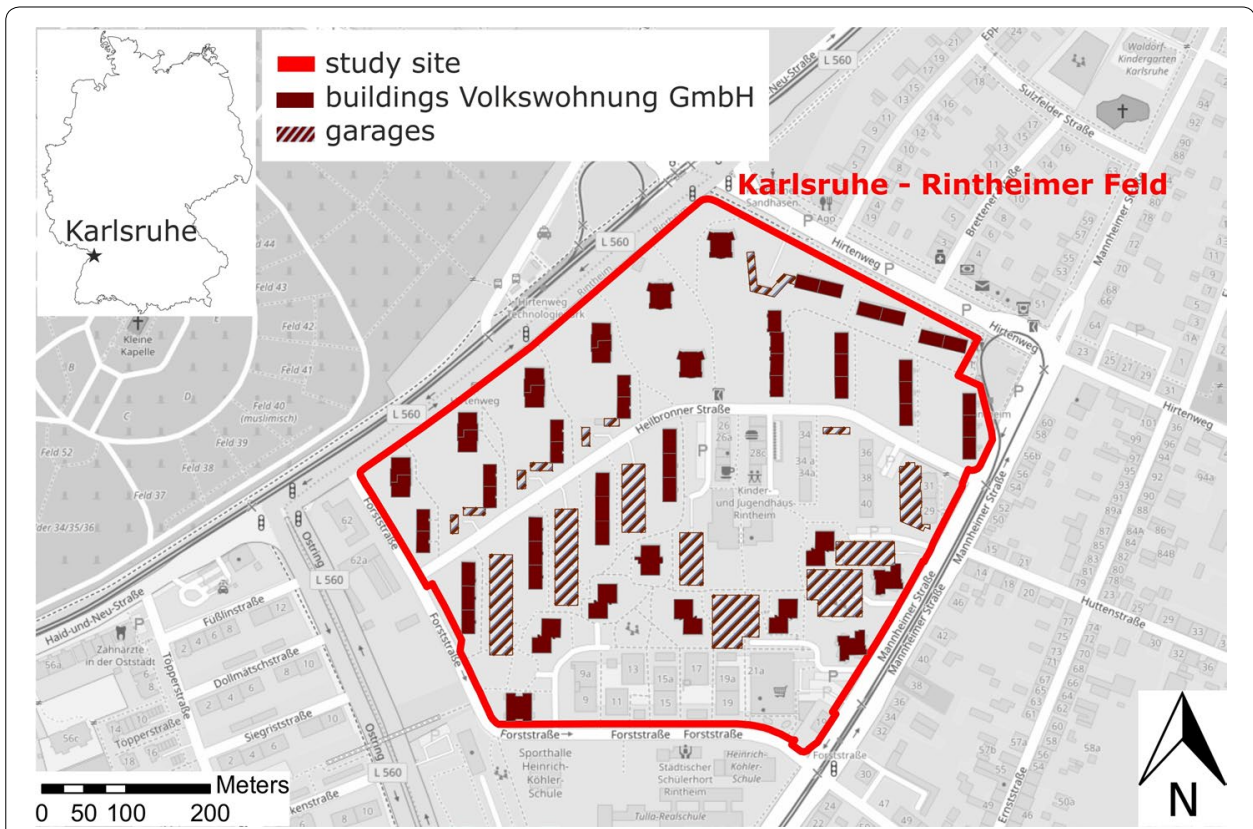

Fig. 1 Overview of the study site "Rintheimer Feld", an urban quarter in the eastern part of Karlsruhe, showing the location of the 31 multi-family houses and of garages

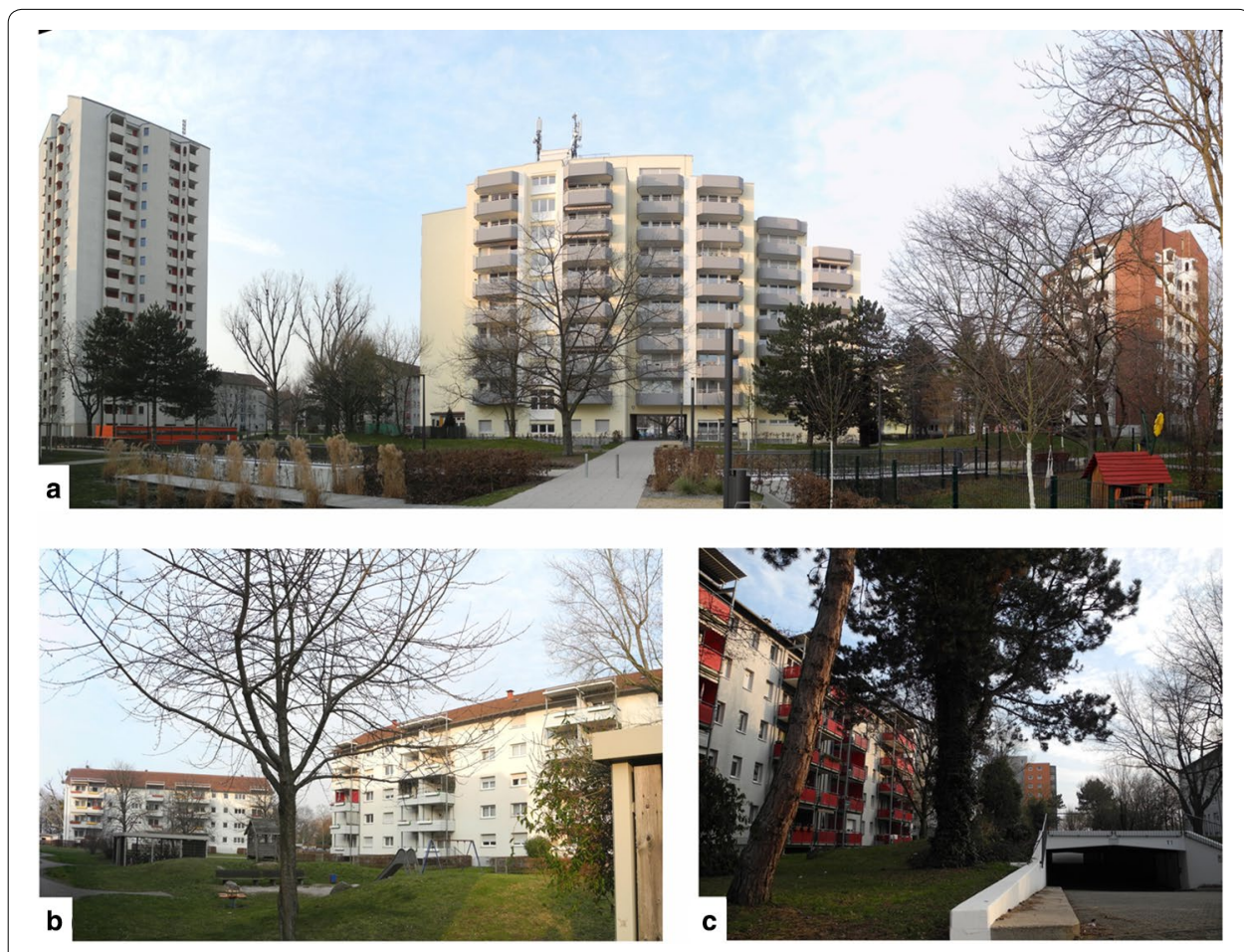

Fig. 2 Impressions of the study site: Housing complexes of the 1950s (b) and high-rise buildings of the 1960 s and 1970s (a) separated by green spaces with trees and shrubbery and playgrounds. Photo c shows an example of an underground car park 
for these two cases is not feasible. For the purpose of an optimized refurbishment, the real estate company collected heat energy data before the refurbishment based on the gas consumption from 2005 to 2007. Since the refurbishment, all buildings are supplied by the municipal district heating network, and installed data loggers record the heat energy consumption on a monthly basis.

\section{Geological and hydrogeological data}

The subsurface of Karlsruhe is characterized by the geology of the Upper Rhine Graben (URG), a Cenozoic continental rift valley mainly filled with Tertiary and Quaternary sands and gravels. The study site is located on a separate structural block close to the main Graben fault and confined by faults to the east and west (Fig. 3).

The hydrogeological map in Fig. 3 and the cross sections in Fig. 4 show the varying structure of the aquifers in the northern and southern part of the study area. In the north, the groundwater body is subdivided into an Upper and Lower Aquifer (LGRB 2005). The Lower Aquifer (LA) has a thickness of $18 \mathrm{~m}$ and is composed of Pliocene fluvial and limnic sediments, such as sands and silts. The Upper Aquifer (UA) consists of gravels and sands with a thickness of $13 \mathrm{~m}$ and represents the only aquifer in the south. Thus, the total aquifer thickness is higher in the north $(31 \mathrm{~m})$ than in the south $(13 \mathrm{~m})$. To protect the Lower Aquifer as a drinking water resource, restrictions for the maximum allowed drilling depth exist in some areas of the URG. According to the online information system for shallow geothermal energy of the state of Baden-Württemberg, called ISONG (LGRB 2017), this restriction of the drilling depth (RDD) is set to $17 \mathrm{~m}$ below

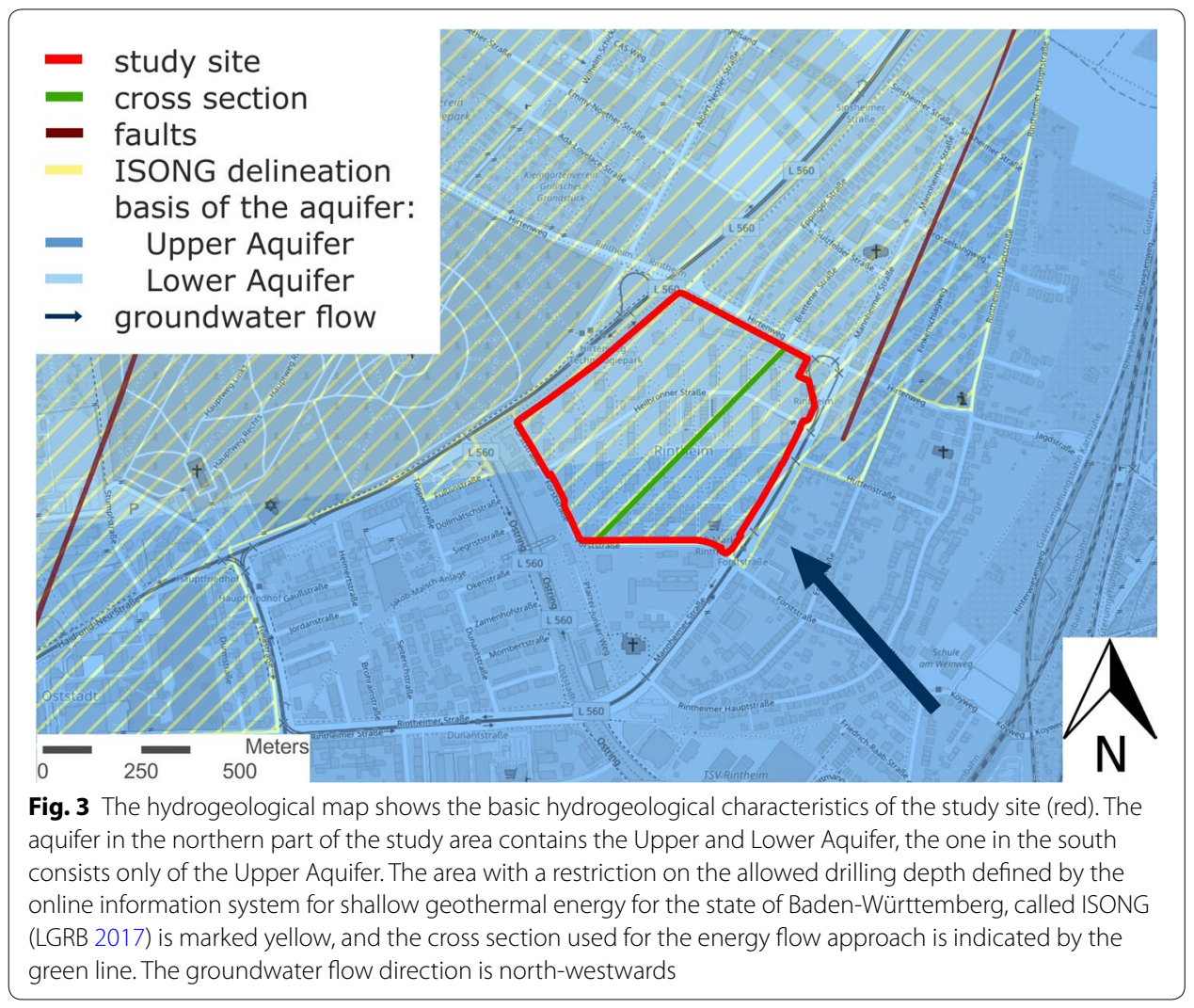




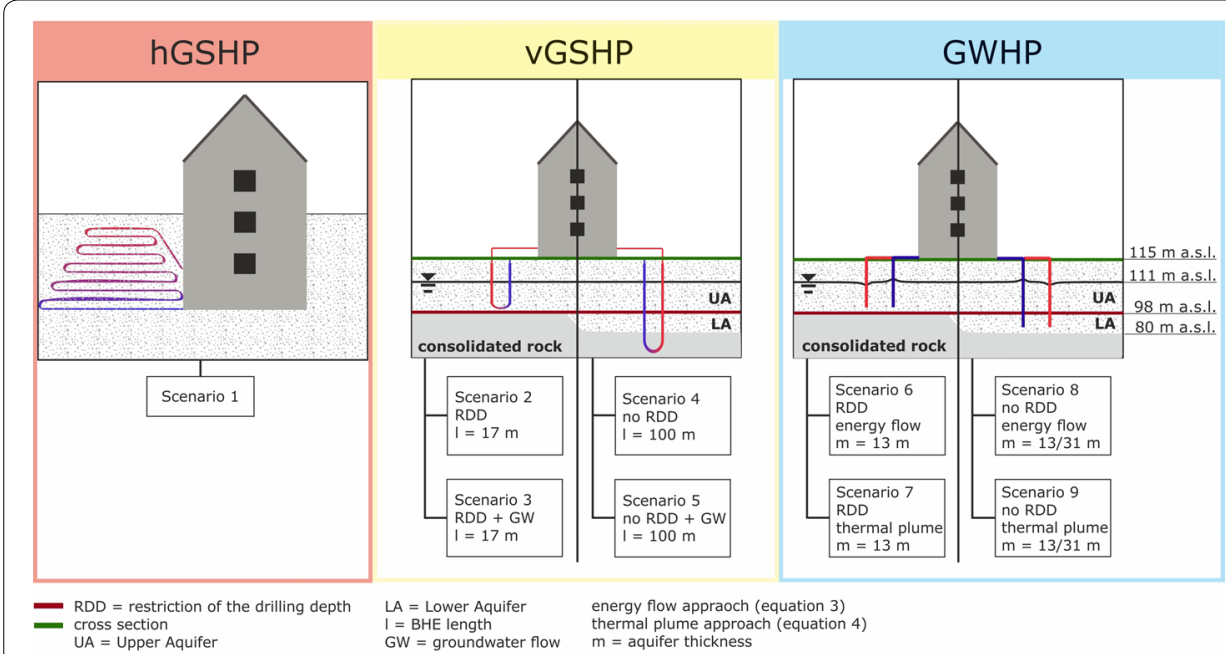

Fig. 4 Illustration of the three studied shallow geothermal systems: horizontal ground source heat pump (hGSHP), vertical ground source heat pump (vGSHP) systems and groundwater heat pump (GWHP) systems. The nine studied scenarios consider variable heat extraction rates $q$ (depending on groundwater flow GW, aquifer thickness $m$, a restriction of the drilling depth (RDD, no RDD), different $B H E$ lengths I, and a fixed borehole heat exchanger (BHE) spacing $d=10 \mathrm{~m}$. The cross-section along the green profile line (Fig. 3) shows the variation in aquifer thicknesses within the study site (UA = Upper Aquifer and $L A=$ Lower Aquifer), the ground level and the depth of the water table

ground level in the entire study site, which is equivalent to the transition depth between the Upper and Lower Aquifer (Fig. 4) in the northern study area. The delineation of the RDD is outlined in Fig. 3 and follows local streets. Underlying both aquifers are Tertiary sedimentary rocks, composed of argillite, marlstone and marly sandstones. All hydrogeological properties, such as hydraulic conductivity and porosity, are listed in Table 3.

\section{Evaluation of the heat supply rate}

The geothermal heat supply rate represents the percentage to which the required thermal energy for heating and DHW can be supplied by a specific geothermal system. Our method for evaluating the heat supply rate for each system is done in three steps. The first step is a spatial analysis using the geographical information system ArcGIS to evaluate the specific space available for each system type. The results of the spatial analysis represent the input parameters for the estimation of the geothermal potential in the second step. The geothermal potential $E$ represents the maximum extractable thermal energy, which can be harnessed annually by each system. To account for the additional energy supplied by a heat pump, a coefficient of performance (COP) of 4 is assumed (Eqs. 2, 3, 4). The impacts of constraints imposed by existing regulations and hydrogeological characteristics are investigated in nine scenarios, which are described in the following subsections. In the third and last steps, we obtain the percental heat supply rate, $S$, by comparing the geothermal potential $E$ for each system, $E_{\mathrm{hGSHP}}, E_{\mathrm{vGSHP}}, E_{\mathrm{GWHP}}$, derived in each scenario with the measured heat consumption before or after refurbishment, $H$ :

$$
S=\frac{E}{H} \cdot 100
$$




\section{Horizontal ground source heat pump (hGSHP) system}

For the hGSHP system, collectors consisting of a horizontal alignment of tubes, which are connected in series or parallel formation, are buried in very shallow depths of a few meters (Baden-Württemberg 2008). The advantages of such hGSHP systems are low investment costs and their suitability for areas with drilling restrictions. However, the collector installation requires a ground surface that is free of shrubbery or trees, sealed surfaces and underground infrastructure, and the required areas are equal to or higher than the heated area of a building.

In the spatial analysis, the available, free area $A_{\mathrm{hGSHP}}$ to install the horizontal system within the study site is derived in ArcGIS based on the available land-use data. For this, the area covered by playgrounds, streets, buildings and garages, as well as a buffer zone of $1 \mathrm{~m}$ for hGSHP around buildings and garages (VDI 4640, part 1 2010) is subtracted from the total area of the study site. This resulting area multiplied by the operational time $t_{\mathrm{h}}$, the heat extraction rate $q_{\mathrm{hGSHP}}$ and the coefficient of performance (COP) yields the geothermal potential $E_{\mathrm{hGSHP}}$ (Eq. 2):

$$
E_{\mathrm{hGSHP}}=q_{\mathrm{hGSHP}} \cdot t_{\mathrm{h}} \cdot A_{\mathrm{hGSHP}} /(1-1 / \mathrm{COP})
$$

In accordance with Ramming (2007), who considers a spacing of the collector tubes of $0.26 \mathrm{~m}$, the same soil type and local climate zone as at our study site, a maximum heat extraction rate $q_{\mathrm{hGSHP}}=33 \mathrm{~W} / \mathrm{m}^{2}$ is applied.

\section{Vertical ground source heat pump (vGSHP) systems}

Vertical GSHP systems use vertically installed plastic tubes, called borehole heat exchangers (BHEs), to harness geothermal and solar energy (Rivera et al. 2015). The standard length for a BHE varies for each country. For example, in the UK, the typical length is $150 \mathrm{~m}$ (Zhang et al. 2014) or in Austria $110 \mathrm{~m}$ (Götzl et al. 2010). In Germany, BHEs typically have a length of up to $100 \mathrm{~m}$, since deeper BHEs require special licensing according to the German federal mining law (BBergG 1980). A detailed overview of the corresponding legislation for the use of shallow geothermal energy is provided by Hähnlein et al. (2010). The advantage of vGSHP systems is a high heat extraction rate of up to $114 \mathrm{~W} / \mathrm{m}$ in cases with favorable groundwater conditions (Erol 2011). However, the drilling costs for the boreholes are higher than for a hGSHP system, and therefore are also a disadvantage of this variant (Blum et al. 2011).

The spatial analysis of the vGSHP system is conducted in ArcGIS within two steps. First, the area available for boreholes is determined. Second, the maximum number of boreholes for a given BHE spacing $d$ is determined. As recommended by the German technical guideline VDI 4640, part 2 (2015), a minimum distance between BHE and the buildings is ensured by setting a buffer zone of $2 \mathrm{~m}$. In contrast, the studies by Zhang et al. (2014) and Miglani et al. (2018) apply a distance of $3 \mathrm{~m}$ between borehole and building. According to Zhang et al. (2014), we assume that BHE can be installed beneath pavements and parking areas. Consequently, in the first step of the spatial analysis, only the area of buildings and garages and a buffer zone of $2 \mathrm{~m}$ around buildings is subtracted from the total area of the RF to obtain the available space for BHE installations. In the second step of the spatial analysis, the ArcGIS tool called "Create Fishnet" is utilized to receive a Cartesian grid with an edge length 
equal to the BHE spacing $d$. This grid is clipped to the available space for BHE installations. The center of each cell represents the location of a BHE; hence, a number $n$ of equally distributed BHEs within the available space are obtained.

After the spatial analysis, the input parameters listed in Fig. 4 and Table 3 are used and Eq. 3 is applied to each scenario to calculate the geothermal potential of the vGSHP system:

$$
E_{\mathrm{VGSHP}}=\sum_{i}^{n} q_{\mathrm{vGSHP}, i} \cdot t_{\mathrm{h}} \cdot l_{\mathrm{VGSHP}, i} /(1-1 / \mathrm{COP})
$$

To account for varying legal and hydrogeological conditions, we have defined four different scenarios for the vGSHP system (Scenarios 2-5, Fig. 4). For all of the four vGSHP scenarios, a conservative BHE spacing of $d=10 \mathrm{~m}$ is applied (Baden-Württemberg 2005). Scenarios 2 and 3 consider the drilling limitation of $17 \mathrm{~m}$ as defined by ISONG $\left(l_{\mathrm{VGSHP}}=17 \mathrm{~m}\right)$. However, to investigate the effect of the given drilling limitation on the geothermal potential and the heat supply rate, a typical BHE length of $l_{\mathrm{VGSHP}}=100 \mathrm{~m}$ is employed for Scenarios 4 and 5 . The heat extraction rate $q_{\mathrm{vGSHP}}=60 \mathrm{~W} / \mathrm{m}$ for Scenarios 2 and 4 is based on the site-specific heat extraction rate suggested by ISONG. In Scenarios 3 and 5, groundwater flow velocities of $0.76-1 \mathrm{~m} / \mathrm{d}$ are considered, suggesting a higher heat extraction rate of $100 \mathrm{~W} / \mathrm{m}$ for the part of the BHE within the aquifer (VDI 4640, part 2 2015). Hence, the BHE length related to the enhanced heat extraction rate is adjusted to the corresponding aquifer thickness in the north $(31 \mathrm{~m})$ and south $(13 \mathrm{~m})$.

The feasibility of higher heat extraction rates for BHEs located in an aquifer with substantial groundwater has proved to be applicable by a local drilling company in Karlsruhe. By application of an innovative hollow stem auger drilling technique, no backfilling material for the BHEs is required, and so the thermal connection between the ground and the BHE is improved (Krämer 2010). In a BHE field experiment, Wang et al. (2009) presented a heat transfer rate improvement by approximately $13 \%$ for an aquifer containing coarse sands and gravels. Also, higher ground and groundwater temperatures positively affect the heat extraction rate. The studies by Benz et al. (2015), Zhu et al. (2015) and Menberg et al. (2013) show that groundwater temperatures beneath cities are up to $7 \mathrm{~K}$ higher compared to rural areas. Due to this so-called subsurface heat island effect, the exploitation rate can be raised from 13 to 33\% (Rivera et al. 2017).

To optimize the system, by minimizing the number of BHEs required to fully meet the heat demand of the study site before and after refurbishment, an additional, inverse analysis is conducted. For this purpose, the values for $t_{\mathrm{h}}, q_{\mathrm{vGSHP}}$ and $l_{\mathrm{vGSHP}}$ are adopted from Scenarios 2 to 5. Furthermore, we assume that $q_{\mathrm{vGSHP}}$ is constant and independent of the BHE spacing (Rivera et al. 2017). The BHE spacing $d$ is adjusted by changing the edge length of the fishnet grid in $0.5 \mathrm{~m}$ steps during the spatial analysis. This adjustment is repeated for each scenario and both, before and after refurbishment until a heat supply of at least $100 \%$ is achieved.

\section{Groundwater heat pump (GWHP) system}

A GWHP system is an open-loop geothermal system, which directly uses groundwater for heating and cooling. The heat is extracted from the pumped groundwater, which 
is reinjected into the aquifer afterwards at a cooler temperature. Since the wells of a GWHP system are typically shallower than the boreholes for BHEs, the total drilling costs are usually lower (Self et al. 2013). A disadvantage is the systems' dependency of groundwater availability and its chemical composition.

For the evaluation of the geothermal potential of GWHP systems, two different approaches are studied: (1) energy flux approach and (2) thermal plume approach. Since the annual average groundwater temperature within the study site is $13.6{ }^{\circ} \mathrm{C}$ (Tiefbauamt, City of Karlsruhe), a maximum tolerable temperature reduction of $\Delta T=6 \mathrm{~K}$ is feasible without falling below the allowed temperature minimum for reinjected water of $5{ }^{\circ} \mathrm{C}$ (Baden-Württemberg 2009b). The results for both approaches are presented with (Scenarios 6, 7) and without (Scenarios 8, 9) consideration of a limited drilling depth.

The energy flux approach enables the estimation of the energy input into the study site due to groundwater flow (Epting and Huggenberger 2013; Mueller et al. 2018). For the spatial analysis of the energy flux approach, the length of the profile sections perpendicular to the groundwater flow direction is determined, which corresponds to the Upper Aquifer as well as the combined Upper and Lower Aquifer (Fig. 3, green line). Multiplying the section lengths with the corresponding thickness $m$ of the aquifers results in two flow areas $A_{\mathrm{UA}}$ and $A_{\mathrm{UA}+\mathrm{LA}}$. The geothermal potential $E_{\mathrm{GWHP}}$ of the heat flux approach is equal to the thermal energy, which is released, when the volume of groundwater flowing through the cross section of the aquifers beneath the study site per year, $Q$, is cooled by $6 \mathrm{~K}$ (Eq. 4b). This volume of groundwater is calculated by Darcy's law (Eq. 4a). In this step, the specific length of the profile obtained by the spatial analysis and the input parameters listed in Table 3 are used to obtain the theoretical geothermal potential $E_{\mathrm{GWHP}}($ Eq. $4 \mathrm{~b})$.

$$
\begin{aligned}
& Q=v_{\mathrm{fUA}} \cdot A_{\mathrm{UA}}+v_{\mathrm{fUA}+\mathrm{LA}} \cdot A_{\mathrm{UA}+\mathrm{LA}} \\
& E_{\mathrm{GWHP}}=Q \cdot t_{\mathrm{y}} \cdot \Delta T \cdot c_{\mathrm{pw}} /(1-1 / \mathrm{COP})
\end{aligned}
$$

In the case of the thermal plume approach, the thermal plume caused by the cold reinjected water is analytically simulated to find the maximum number of wells without an interference of the 1-K isotherm. Similar to the spatial analysis for the vGSHP system, the ArcGIS tool "Create Fishnet" is used to design a rectangular grid with the edge length equal to the maximum thermal plume dimension of the $1-\mathrm{K}$ isotherm. Since the thermal plumes have to be oriented in groundwater flow direction and the created fishnet is north-south directed, the fishnet is rotated in the same direction (NW). The center of each grid cell defines a possible well location. The following Eq. 5 by Kinzelbach (1992) is currently used in the guideline for the use of small GWHP systems (< 45,000 kWh/year) by the Federal State of Baden-Württemberg (Baden-Württemberg 2009a). It represents an analytical solution to estimate the thermal plume length and width due to advection and conduction.

$$
\begin{aligned}
\Delta T(x, y, t) & =\frac{Q \cdot \Delta T}{4 \cdot p \cdot m \cdot v_{\mathrm{a}} \cdot \sqrt{\pi \cdot \alpha_{\mathrm{T}}}} \cdot \exp \left(\frac{x-r}{2 \cdot \alpha_{\mathrm{L}}}\right) \cdot \frac{1}{\sqrt{r}} \cdot \operatorname{erfc}\left(\frac{r-v_{\mathrm{a}} \cdot t / R}{2 \cdot \sqrt{v_{\mathrm{a}} \cdot \alpha_{\mathrm{L}} \cdot t / R}}\right) \\
r & =\sqrt{x^{2}+y^{2} \frac{\alpha_{\mathrm{L}}}{\alpha_{\mathrm{T}}}}
\end{aligned}
$$


Considering the different properties of the Upper Aquifer and combined Upper and Lower Aquifer, the thermal plumes for $1-\mathrm{K}, 2-\mathrm{K}$ and $3-\mathrm{K}$ isotherms are simulated at every well location and plotted in ArcMap (Fig. 5c). For this purpose, Eq. 5 is implemented in Python, which has an interface with ArcGIS. The well coordinates $x$ and $y$ are the results from the spatial analysis, while the remaining input parameters are listed in Table 3. Since Eq. 5 is only valid for small systems with $<45,000 \mathrm{kWh} /$ year, which corresponds to $Q$ values between 0.1 and $0.3 \mathrm{l} / \mathrm{s}$, the pumping rate $Q$ is set to $0.2 \mathrm{l} / \mathrm{s}$ per well (Baden-Württemberg 2009a; Pophillat et al. 2018). The technical geothermal potential for the thermal plume approach is computed by multiplying the energy supplied per GWHP system (Eq. 4b) with the total number of wells $n$.

\section{Results and discussion}

This section is structured as follows: first, the results of the spatial analysis, the geothermal potential and the heat supply rate of the heat demand before and after refurbishment for each system and scenario are presented. Second, we investigate how the BHE spacing of the vGSHP system has to be adapted to achieve a heat supply rate of at least $100 \%$ before and after refurbishment. Third, the results for all systems are compared and discussed with those from related studies.

\section{Horizontal ground source heat pump (hGSHP) system}

The spatial analysis for the hGSHP system shows that $60 \%$ (i.e., $80,032 \mathrm{~m}^{2}$ ) of the original surface area can be used to install collectors, as illustrated in red in Fig. 5a. The corresponding geothermal potential results in a heat supply rate of $59 \%$ before refurbishment, and $125 \%$ afterwards. However, the heat supply rate would be lower, if the open space and subsurface occupied by vegetation and subsurface infrastructure, such as sewers and underground cables, were incorporated. The effects of the bending number of the collector tubes, burial depth or a different pipe spacing on the thermal performance of the hGSHP system also have to be considered (Pu et al. 2018). In addition, the heat extraction rate in the shadow of trees and buildings might be lower than the assumed $33 \mathrm{~W} /$

$\mathrm{m}^{2}$. Since the heat supply rate after refurbishment exceeds the required percentage by $25 \%$, a satisfying result should be still ensured even if a further reduction in surface area due the above issues are considered.

\section{Vertical ground source heat pump (vGSHP) system}

The spatial analysis yields the maximum number of BHE positions and available area for the system installation. Based on the assumption that BHEs can be installed beneath bituminized areas, the available space for the vertical system installation is $10 \%$ larger than the area for the horizontal system. In the case of a standard 10m BHE spacing for Scenarios 2-5, 974 BHEs can be installed.

Table 1 provides the geothermal potential and heat supply rate for a $\mathrm{COP}=4$ of the four scenarios with a standard 10-m BHE spacing. Regarding Scenarios 2 and 3 in comparison to Scenarios 4 and 5, the impact of the RDD is obvious. The geothermal potential rises by a factor of 5.9 and 4.5, respectively, if a BHE length of $100 \mathrm{~m}$ is employed. The 
geothermal potential of Scenario 3 is 1.5 times higher than of Scenario 2, which demonstrates the significant impact of the groundwater flow and the corresponding increase in the heat extraction rate on the geothermal potential. The improvement from Scenario 4 to 5 is by a factor of 1.2. So, with an increasing BHE length, the influence of the groundwater flow diminishes. This implies that the length of a BHE has a large influence on the geothermal potential. This is in accordance with the results by Casasso and Sethi (2014)

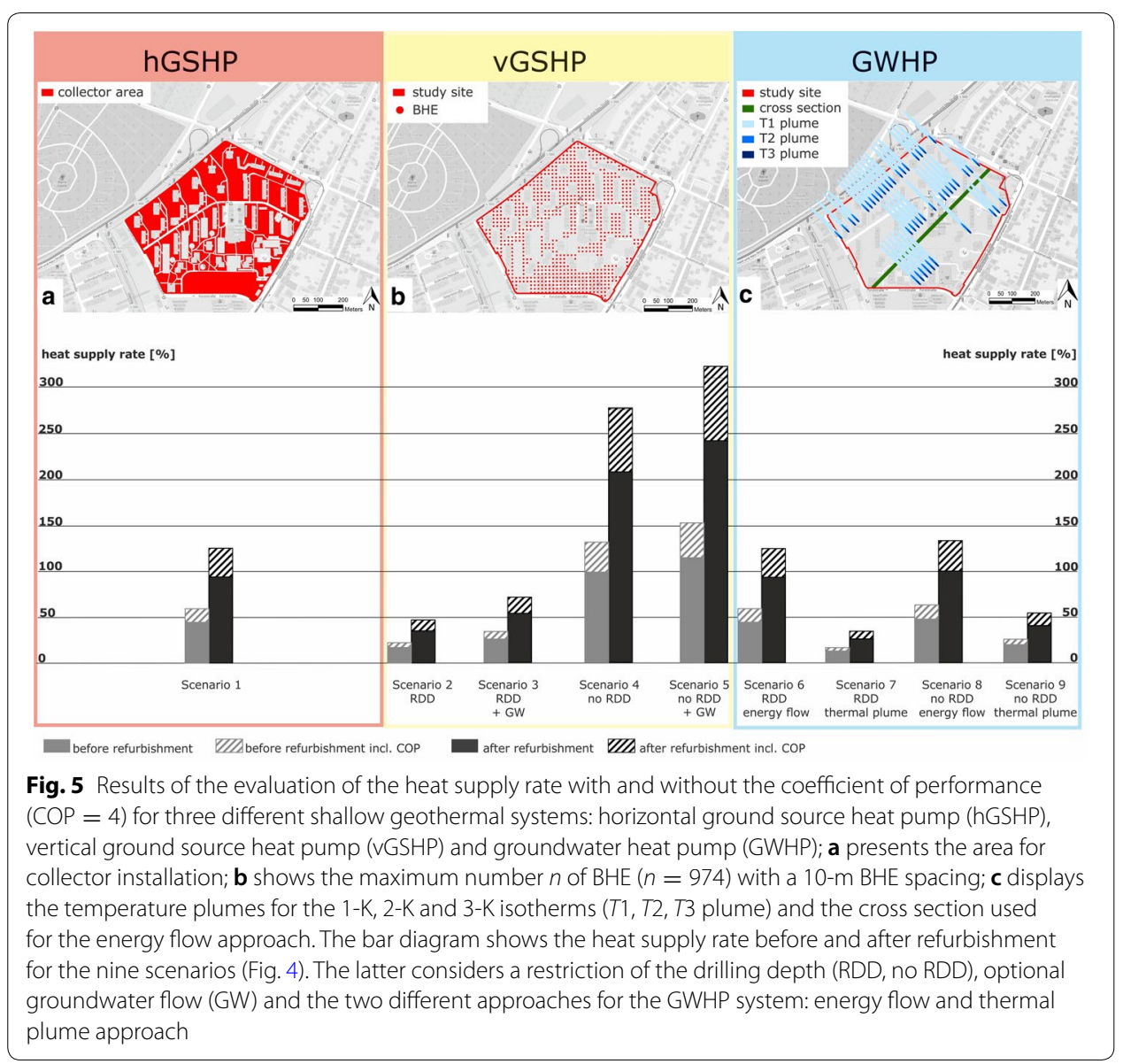

Table 1 Results of the estimation of the geothermal potential for the vGSHP system with a COP $=4$ for Scenarios 2 to 5 and the heat supply rate $S$ before and after refurbishment with a fixed BHE spacing

\begin{tabular}{|c|c|c|c|c|c|c|c|}
\hline \multirow[t]{3}{*}{ Scenario } & \multicolumn{3}{|c|}{ Fixed BHE spacing $d=10 \mathrm{~m}$} & \multicolumn{4}{|c|}{ Inverse analysis } \\
\hline & \multirow[t]{2}{*}{$E(G W h)$} & \multicolumn{2}{|l|}{$S(\%)$} & \multicolumn{2}{|c|}{ BHE spacing $(m)$} & \multicolumn{2}{|c|}{ Number of BHE } \\
\hline & & Before & After & Before & After & Before & After \\
\hline 2: RDD & 2.3 & 22 & 47 & 4.5 & 6.5 & 4675 & 2242 \\
\hline 3: RDD + GW & 3.4 & 34 & 71 & 5.5 & 8 & 3121 & 1473 \\
\hline 4: no RDD & 13.3 & 131 & 277 & 11 & 16 & 783 & 377 \\
\hline 5: no RDD + GW & 15.4 & 152 & 322 & 12 & 17.5 & 657 & 302 \\
\hline
\end{tabular}

Results of the inverse analysis: the minimum BHE spacing and number of BHEs for which a heat supply rate of at least $100 \%$ before or after refurbishment can be achieved. The four scenarios consider variable heat extraction rates $q$ depending on groundwater flow (GW) and two different BHE lengths $(17 \mathrm{~m}$ and $100 \mathrm{~m}$ ) corresponding to the restriction of the drilling depth (RDD, no RDD) 
and Schiel et al. (2016), who concluded that the BHE length has the largest impact on the heat supply rate.

Due to the RDD, Scenarios 2 and 3 attain only a heat supply rate of maximum $71 \%$ before and after refurbishment. Assuming a standard heat extraction rate of $60 \mathrm{~W} / \mathrm{m}$ and no restriction of the drilling depth, the heat demand before refurbishment can be entirely satisfied by a vGSHP system. Due to higher heat extraction rates for Scenario 5 , the heat supply rate before refurbishment is even higher. After refurbishment, the heat demand can be satisfied more than twice for both Scenarios 4 and 5 .

To optimize the BHE spacing and determine the minimum number of BHEs required to achieve a heat supply rate of at least $100 \%$ before ( $E_{\mathrm{VGSHP}} \approx 10 \mathrm{GWh}$ ) and after $\left(E_{\mathrm{VGSHP}} \approx 5 \mathrm{GWh}\right)$ refurbishment for Scenarios 2-5, the BHE spacing is adjusted accordingly and inversely obtained. Table 1 illustrates the huge variation in BHE spacing between 4.5 and $17.5 \mathrm{~m}$ depending on the particular combination of calculation input parameters. In view of the official regulation of the VDI 4640, part 2 (2001), a BHE spacing of $4.5 \mathrm{~m}$, however, would not be acceptable. So, for Scenario 2, the energy demand can only be satisfied after refurbishment and a BHE spacing of $6.5 \mathrm{~m}$ which is consistent with the official regulatory framework.

Attention should be paid to the large number of BHEs for Scenarios 2 and 3. The space for the system installation is sufficient but the required number of BHEs is unrealistically high and approaches the limit of practicability and cost efficiency. Moreover, our approach does not incorporate potential thermal interaction between individual BHEs or any dynamic effects over the lifetime of a BHE field. If the spacing is too small and/or the actual heat extraction too large, the subsurface could cool down due to a lack of thermal regeneration, and the system might become inefficient. The heat extraction rate of a BHE field investigated by Fujii et al. (2005) with 75 BHEs with 50$\mathrm{m}$ length and a spacing of $7.6 \mathrm{~m}$, situated in Quaternary silts and fine sands, fell by $55 \%$ after a simulation period of 50 years. In contrast, the study by Kurevija et al. (2012) showed that for a 9-m spacing, thermal interference could be neglected. Based on the heating and cooling conditions of a new building in Zagreb, Croatia, they studied the effects of BHE geometry and spacing on the performance of the system and thermal interference of the BHE. The optimal spacing for 42 BHEs, regarding economic and efficiency aspects, was $6 \mathrm{~m}$. Also, the study by De Carli et al. (2014) obtained a range in BHE spacing comparable to the one of our case study. In their case, the spacing depended on the energy demand of the housing district and the shape of the BHE field. For different BHE field configurations, the spacing varied between 6 and $15 \mathrm{~m}$. Alcaraz et al. (2017) developed a method called T-I-GER which aims to optimize the position of BHE and maximize the extraction potential while at the same time minimizes the thermal impact on neighboring plots. Furthermore, a reduction in BHE spacing or increase in total BHE length without a strong decline of the ground temperature or a degradation of the longterm performance is feasible if a thermal regeneration of the ground during summer is incorporated in the optimization. Long-term studies by Pahud (2015) showed a decrease of the system performance of BHE fields (3-62 BHEs having a spacing of 5-9 $\mathrm{m}$ ) after several years. He proposed two potential strategies to overcome this challenge: a reduction of the peak performance or thermal regeneration of the field. Kübert et al. (2010) included an annual regeneration of the BHE field due 
to the heat supply by a cogeneration unit. So they could reduce the total BHE length by $25 \%$ and determined $10 \mathrm{~m}$ as an optimal spacing for a field of 50 BHEs à $115 \mathrm{~m}$ length. Bayer et al. (2014) demonstrated the regeneration of a BHE field by seasonal geothermal heating and cooling operation. These studies and other guidelines in Germany (Hähnlein et al. 2011), where the required minimum distances are $5 \mathrm{~m}$ and $6 \mathrm{~m}$, respectively, clearly indicate that the recommended spacing of $10 \mathrm{~m}$ by the guideline of Baden-Württemberg (2005) is a very conservative assumption. Thus, regardless of the case-specific properties or respective approach, an optimization of the BHE spacing and adaption to local hydrogeological conditions should always be carried out to maximize the systems' performance.

\section{Groundwater heat pump (GWHP) system}

According to the spatial analysis for the energy flux approach, the profile line of the cross section in Fig. 3 has a length of $448 \mathrm{~m}$, with $203 \mathrm{~m}$ corresponding to the Upper Aquifer and $245 \mathrm{~m}$ to the Upper and Lower Aquifer. Consequently, the flow area is $2639 \mathrm{~m}^{2}$ and $7595 \mathrm{~m}^{2}$, respectively. For Scenario 6, Eq. 4a yields a volumetric flow $Q$ of $20.4 \mathrm{l} / \mathrm{s}$ per year and a corresponding geothermal potential of $5.94 \mathrm{GWh}$. In relation to the heat demand, this returns a heat supply rate of $59 \%$ before, and $124 \%$ after refurbishment. For Scenario 8 without the RDD, the volumetric flow $Q$ is $6.7 \%$ higher and the geothermal potential amounts to $6.37 \mathrm{GWh}$.

For the thermal plume approach (Scenario 7 and 9), the dimension of the $1-\mathrm{K}$ isotherm was used as input data for the spatial analysis. In total, the geothermal potential is 1.63 GWh for Scenario 7 and 2.57 GWh for Scenario 9 (Table 2).

The thermal plumes are shorter and narrower in the northern part (Fig. 5c and Table 2), as the same amount of thermal energy (i.e., 45,000 kWh) is exchanged with a larger volume of water due to larger aquifer thickness than in the Southern part. As a result of this and due to the different proportion of the available area, thirty additional reinjection wells can be set up in the north without an interference of the 1-K isotherm in Scenario 9. Due to the RDD in Scenario 7, only the Upper Aquifer is used as an energy source. As a result of the larger plume dimensions for the Upper Aquifer, only 28 instead of 44 wells could be installed without an interference of the $1-\mathrm{K}$ isotherm.

Comparing these results with other studies highlights the variability in plume dimension in dependence on the aquifer thickness and design of the GWHP system. Keim and Lang (2008) employed a pumping rate $Q=0.3 \mathrm{l} / \mathrm{s}$, a temperature reduction of $4 \mathrm{~K}$, a groundwater velocity of $1.2 \mathrm{~m} /$ day and also a heat extraction of 45,000 $\mathrm{kWh} /$ year and

Table 2 Results of the spatial analysis and estimation of the geothermal potential for the GWHP system: maximal extension of the 1-K isotherm in $x$ and $y$-direction, the number of wells, geothermal potential

\begin{tabular}{|c|c|c|c|c|c|c|c|}
\hline \multirow[t]{2}{*}{ Scenario } & \multirow[t]{2}{*}{ Area } & \multirow[t]{2}{*}{$\operatorname{Max} x(\mathrm{~m})$} & \multirow[t]{2}{*}{$\operatorname{Max} y(\mathrm{~m})$} & \multirow{2}{*}{$\begin{array}{l}\text { Number } \\
\text { of wells }\end{array}$} & \multirow[t]{2}{*}{$E(\mathrm{GWh})$} & \multicolumn{2}{|l|}{$S(\%)$} \\
\hline & & & & & & Before & After \\
\hline 7 & UA & 162 & 13 & 28 & 1.6 & 16 & 34 \\
\hline \multirow[t]{2}{*}{9} & UA & 162 & 13 & 7 & 0.4 & 25 & 54 \\
\hline & $U A$ and $L A$ & 127 & 12 & 37 & 2.2 & & \\
\hline
\end{tabular}

UA Upper Aquifer, LA Lower Aquifer 
well. Their study considered two cases, the first case with an aquifer thickness of $10 \mathrm{~m}$ and the second case with $30 \mathrm{~m}$. For the first case, they received a maximum plume dimension of the $1-\mathrm{K}$ isotherm of $x=461 \mathrm{~m}$ and $y=28 \mathrm{~m}$, for the second case is $x=$ $175 \mathrm{~m}$ and $y=10 \mathrm{~m}$. The plume width of the second case is about the size of the one in Scenario $9(m=31 \mathrm{~m})$. Contrasting the results of their first case with Scenario 7, we obtained a plume length that is only a third. This discrepancy is caused by the differences in the above-listed input parameter especially in the aquifer thickness and pumping rate. Consequently, a smaller aquifer thickness, for example, due to a RDD, leads to longer and wider plumes; so, fewer well locations are feasible and the overall heat supply rate is lower. If the thermal plumes are too long and cross the property line, the neighboring parcel might be thermally affected. This could lead to a decrease in the system efficiency of the neighboring geothermal system or, depending on the local legislation, the GWHP system would need to be shut down. For this reason, a detailed 3D geological model and a numerical groundwater flow model on the city level are desirable to properly plan a GWHP and avoid interactions of neighboring systems.

When contrasting the results of the energy flow with the thermal plume approach, it is essential to notice that the energy flow approach represents the maximum available thermal energy and neither regards any technical conditions nor pays attention to overlapping isotherms or well positions. In contrast, the thermal plume approach is a more thorough method with several input parameters taking into account well configurations. As mentioned in "Groundwater heat pump (GWHP) system" section, the pumping rate $Q$ for the thermal plume approach is limited to $0.2 \mathrm{l} / \mathrm{s}$ per well, and accordingly, the total $Q$ for scenario 7 is $5.6 \mathrm{l} / \mathrm{s}$ and $8.8 \mathrm{l} / \mathrm{s}$ for Scenario 9 . In contrast, the flow rate obtained with the energy flow approach in Scenarios 6 and 8 is $27 \%$ and 34\% higher. The constraints of the thermal plume approach, such as a lower pumping rate and a limited number of wells, thus explain the smaller geothermal potential and heat supply rate in comparison to the one of the energy flux approach.

\section{Comparison}

The results of the spatial analysis and the evaluation of the heat supply rate of all nine scenarios before and after refurbishment with and without the portion of a heat pump are summarized in Fig. 5. Standing out is the high heat supply rate of the vGSHP system in Scenarios 4 and 5 (without RDD) before and after refurbishment. Thus, the vGSHP is the optimal geothermal system to satisfy the heat demand of this study site. The results of the GWHP system demonstrate that theoretically, the energy available in the aquifer is sufficient to satisfy the heat demand after refurbishment. Yet, in practice, this geothermal potential cannot be fully extracted, if an overlapping of thermal plumes has to be avoided. Hence, the smallest heat supply rates are obtained in Scenarios 7 and 9. The larger aquifer thickness in the northern part enables deeper wells for a GWHP system or a higher heat extraction rate for BHE. Thus, the northern part is more suitable and economically attractive for vGSHP and GWHP systems. Interestingly, the hGSHP system achieves a full heat supply rate after refurbishment. The advantage of this system is its independence of drilling limitations and so it is the best alternative to the vGSHP system if we regard the RDD by ISONG. 
A detailed inspection of Fig. 3 reveals the deviation between the outline of the drilling limitation defined by ISONG and the boundary between the two bases of the aquifers. The delineation runs sharply and angularly along streets instead of following the hydrogeological and/or tectonic boundaries. Within the study site, the drilling depth is limited to $17 \mathrm{~m}$, yet on the other side of the local street, the "Forststraße" in the south, there is no RDD. In addition, the hydrogeological map in Fig. 3 and the cross sections in Fig. 4 imply that there is no separating layer, such as an aquitard, between the two aquifers, which could protect the Lower Aquifer from contamination.

Consequently, detailed and permanently updated geological and hydrogeological data are necessary for a technical feasibility study and to improve the knowledge of underground risks to avoid negative effects. Epting et al. (2013) also criticize the lack of information and recommend a sustainable thermal management of the subsurface that includes 3D numerical groundwater flow and heat transport models as well as monitoring systems. Aside from this, possible conflicts of interest with subsurface infrastructure such as sewage systems and tunnels have to be detected and considered in a sustainable thermal management of the subsurface. Thus, in practice, geothermal systems might not be considered, due to the lack of true and reliable information.

Besides regulations and local hydrogeological conditions, the ratio from available space for a system installation to heat demand is a decisive factor for a satisfying heat supply rate. In our study, $60-70 \%$ of the area is utilizable for hGSHP, vGSHP and GWHP system installations. In denser urban areas, this space is likely to be smaller and due to higher buildings with a larger heat demand per $\mathrm{m}^{2}$ building, we expect the heat supply rate to be smaller in such areas unless the amount of overall drilling meter increases significantly. The latter was demonstrated in the case study by De Carli et al. (2014), who proposed to identify the most suitable BHE solution for an urban area with two different building density types. They defined a low-density housing district with 2-floor buildings, and a medium-density housing district composed of buildings with six floors. The available space for the system installation is equal for both districts, yet the heat demand is more than two times higher for the district with higher buildings, which raised the required total BHE length from 13,860 to 40,000 m. Relating this result to Scenario 4 and an optimal spacing, the total BHE length increases from 37,700 to $78,300 \mathrm{~m}$, comparing the heat supply rate after refurbishment to the one before. So, the two cases before and after refurbishment with their different heat demands can also be transferred and correlated with the cases having a high and low building density or high- and low-rise buildings.

The study by Schiel et al. (2016) also confirmed that the possibility to meet the heat demand in Germany, in particular with a low number of BHEs, is more likely in a residential, less dense urban quarter with low-rise buildings. In their study, the heat demand of only $40 \%$ of the parcels in an urban area with 87,000 inhabitants could be satisfied by vGSHP systems. In a case study investigating the district of Westminster in London, Zhang et al. (2014) reported that the heat demand of $69 \%$ of the buildings could be completely supplied by vGSHP systems. They also stated that only buildings with five floors or less and a maximum heat demand of $40 \mathrm{~W} / \mathrm{m}^{2}$ fall within this range. This low heat demand refers to the refurbished buildings in our case study (Table 3). Since the number of BHEs or the total BHE length is not mentioned by Schiel et al. (2016) or Zhang et al. 
(2014), a direct comparison to our results is not feasible. Nevertheless, these studies and our case study illustrate that a full heating energy supply by vGSHP systems is a challenging, yet achievable task in dense urban areas. A heat supply rate of $100 \%$ is feasible if sufficient space for system installation is available or in the case of an area with low-rise buildings or buildings with a low energy demand.

\section{Conclusion}

Based on a case study in a German urban quarter, we conducted a technical feasibility study under consideration of influencing and restrictive factors for the application of shallow geothermal systems. We considered three different shallow geothermal systems, namely horizontal (hGSHP) and vertical ground source heat pump (vGSHP) as well as groundwater heat pump (GWHP) systems. The results of this study highlight the capability of each system to satisfy the heat demand for space heating and domestic hot water before and after the refurbishment of an urban quarter in Karlsruhe.

The results demonstrate that the heat demand of an old non-refurbished urban quarter in Germany can be satisfied by a vGSHP system installed at a standard depth of $100 \mathrm{~m}$. In the case of the GWHP system, the energy available in the aquifer suffices to meet the heat demand after refurbishment. Yet, when we apply an analytical model to avoid an interaction between thermal plumes, the heat supply rate declines to less than $54 \%$. After refurbishment, the hGSHP system could also meet the heat demand with a heat supply rate of $125 \%$. Thus, it is a decent alternative to the vGSHP system in the case of a restriction of the drilling depth.

We identify four major influencing and restrictive factors for the efficiency of shallow geothermal systems and the achievement of a full heat supply rate. First, there is the restriction of the drilling depth by authorities. Second, guidelines for critical design parameters provide conservative recommendations for heat extraction rates $(60 \mathrm{~W} / \mathrm{m})$ and BHE spacing $(10 \mathrm{~m})$. For an optimal system planning, better knowledge of crucial physical parameters is mandatory and can be obtained by, for example, a thermal response test (TRT). Third, favorable hydrogeological conditions, such as a moderate to high groundwater flow velocity, a sufficient aquifer thickness or thermal conductivity, are fundamental. Fourth, an optimal ratio of available space for system installation to heat demand is decisive for achieving a satisfactory heat supply rate.

We anticipate that our straightforward evaluation of the geothermal heat supply rate combined with a profound geological knowledge will reveal the ability of geothermal systems to satisfy the heat demand of any urban area. This way, it will help to realize future urban energy plans. Moreover, as climate changes, air temperatures in summertime and the demand for building cooling will increase. Cooling can also be supplied by geothermal systems while enhancing the thermal regeneration of the subsurface. Other subsurface structures, such as tunnels and sewer systems, should be incorporated in a further development of the spatial analysis. A single coefficient of performance (COP) for all three systems facilitates comparisons of the results, yet in the future, the COP has to be adapted to the individual systems. 
Table 3 Input parameters for the estimation of the heat supply rate

\begin{tabular}{|c|c|c|}
\hline Parameter & Symbol & Value \\
\hline \multicolumn{3}{|l|}{ Hydrogeology } \\
\hline \multirow[t]{3}{*}{ Darcy velocity ${ }^{\mathrm{a}}$} & $V_{f \cup A}$ & $3.5 \times 10^{-6} \mathrm{~m} / \mathrm{s}$ \\
\hline & $V_{f L A}$ & $3.3 \times 10^{-7} \mathrm{~m} / \mathrm{s}$ \\
\hline & $V_{f \cup A}+\mathrm{LA}$ & $1.76 \times 10^{-6} \mathrm{~m} / \mathrm{s}$ \\
\hline \multirow[t]{3}{*}{ Groundwater velocity ${ }^{\mathrm{a}}$} & $V_{a U A}$ & $1.17 \times 10^{-5} \mathrm{~m} / \mathrm{s}$ \\
\hline & $V_{\mathrm{aLA}}$ & $1.65 \times 10^{-6} \mathrm{~m} / \mathrm{s}$ \\
\hline & $V_{\mathrm{aUA}}+\mathrm{LA}$ & $8.78 \times 10^{-6} \mathrm{~m} / \mathrm{s}$ \\
\hline \multirow[t]{3}{*}{ Porosity $^{b}$} & $p_{\cup A}$ & 0.2 \\
\hline & $p_{\mathrm{LA}}$ & 0.1 \\
\hline & PUA+LA & 0.14 \\
\hline \multirow[t]{3}{*}{ Hydraulic conductivity $^{c}$} & $K_{\cup A}$ & $3.5 \times 10^{-3} \mathrm{~m} / \mathrm{s}$ \\
\hline & $K_{\mathrm{LA}}$ & $3.3 \times 10^{-4} \mathrm{~m} / \mathrm{s}$ \\
\hline & $K \cup A+L A$ & $1.66 \times 10^{-3} \mathrm{~m} / \mathrm{s}$ \\
\hline Hydraulic gradient $^{d}$ & i & 0.001 \\
\hline \multirow[t]{3}{*}{ Aquifer thickness ${ }^{\mathrm{e}}$} & $m \cup A$ & $13 \mathrm{~m}$ \\
\hline & $m_{\llcorner A}$ & $18 \mathrm{~m}$ \\
\hline & $m \cup A+L A$ & $31 \mathrm{~m}$ \\
\hline Longitudinal thermal dispersivity ${ }^{f}$ & $a_{\llcorner}$ & $3.4 \mathrm{~m}$ \\
\hline Transversal thermal dispersivity ${ }^{9}$ & $a_{\top}$ & $0.34 \mathrm{~m}$ \\
\hline Retardation factor ${ }^{h}$ & $R$ & 2 \\
\hline Volumetric heat capacity of water ${ }^{i}$ & $C_{\mathrm{pw}}$ & $4.16 \times 10^{6} \mathrm{~J} / \mathrm{m}^{3} \mathrm{~K}$ \\
\hline \multicolumn{3}{|l|}{ Geothermal system } \\
\hline Relative annual operation period (heating $+\mathrm{DHW})^{\mathrm{j}}$ & $t_{\mathrm{h}}$ & $1700 \mathrm{~h}$ \\
\hline Heat extraction rate hGSHPk & $q_{\text {hGSHP }}$ & $33 \mathrm{~W} / \mathrm{m}^{2}$ \\
\hline \multirow[t]{2}{*}{ BHE length } & $I_{\mathrm{VGSHP}}{ }^{\mathrm{m}}$ & $17 \mathrm{~m}$ \\
\hline & $I_{V G S H P}$ & $100 \mathrm{~m}$ \\
\hline \multirow[t]{2}{*}{ Heat extraction rate vGSHP } & $q_{\mathrm{VGSHP}}$ & $60 \mathrm{~W} / \mathrm{m}$ \\
\hline & $q_{\mathrm{vGSHP}}{ }^{\mathrm{i}}$ & $100 \mathrm{~W} / \mathrm{m}$ \\
\hline Hours per year & $t_{\mathrm{y}}$ & $8760 \mathrm{~h}$ \\
\hline Temperature difference ${ }^{g}$ & $\Delta \mathrm{T}$ & $6 \mathrm{~K}$ \\
\hline Time after reinjection ${ }^{9}$ & $t$ & $1000 d$ \\
\hline Coefficient of performance ${ }^{g, n}$ & COP & 4 \\
\hline \multicolumn{3}{|l|}{ Rintheimer Feld ${ }^{j}$} \\
\hline Number of refurbished buildings & & 31 \\
\hline Area RF & $A_{\text {RF }}$ & $0.13 \mathrm{~km}^{2}$ \\
\hline Average space heating demand: before refurbishment & $h_{\mathrm{b}}$ & $136 \mathrm{kWh} / \mathrm{m}^{2}$ \\
\hline Average space heating demand: after refurbishment & $h_{\mathrm{a}}$ & $50 \mathrm{kWh} / \mathrm{m}^{2}$ \\
\hline Total thermal energy demand: before refurbishment & $H_{b}$ & $10.12 \mathrm{GWh}$ \\
\hline Total thermal energy demand: after refurbishment & $H_{a}$ & $4.79 \mathrm{GWh}$ \\
\hline
\end{tabular}

UA Upper Aquifer, LA Lower Aquifer

a Calculated based on Hölting and Coldewey (2013)

b Busch et al. (1974)

c Wirsing and Luz (2007)

d Tiefbauamt, City of Karlsruhe

e LGRB (2005)

f Beims (1983)

g Baden-Württemberg (2009a)

h Molina-Giraldo (2011)

i VDI 4640, part 2 (2001)

j Jank and Kuklinski (2015)

k Ramming (2007)

I BBergG (1980)

m LGRB (2017)

n Miglani et al. (2018) 


\section{List of symbols Latin symbols}

$A$ : area $\left(\mathrm{m}^{2}\right) ; c_{\mathrm{pw}}$ : volumetric heat capacity $\left(\mathrm{J} /\left(\mathrm{m}^{3} \mathrm{~K}\right)\right)$; BHE: borehole heat exchanger; $d$ : BHE spacing (m); COP: coefficient of performance; DHW: domestic hot water; $E$ : geothermal potential (GWh); GIS: geographical information system; $H$ : heat demand (GWh); GW: groundwater flow; $K$ : hydraulic conductivity $(\mathrm{m} / \mathrm{s}) ; l$ length of a BHE $(\mathrm{m})$; $m$ : aquifer thickness $(\mathrm{m}) ; n$ : number; $p$ : porosity; $q$ : heat extraction rate $\left(\mathrm{W} / \mathrm{m}^{2}, \mathrm{~W} / \mathrm{m}\right)$; $Q$ : water discharge rate/pumping rate $(\mathrm{l} / \mathrm{s}) ; R$ : retardation; $r$ : radial coordinate $(\mathrm{m})$; RDD: restriction of the drilling depth; $S$ : heat supply rate; $\Delta T$ : temperature difference $(\mathrm{K}) ; t$ time (s, h, d) T1, T2, T3: $1 \mathrm{~K}, 2 \mathrm{~K}$ and $3 \mathrm{~K}$ temperature isotherms of the thermal plumes; URG: Upper Rhine Graben; $v_{a}$ : groundwater velocity $(\mathrm{m} / \mathrm{s}) ; v_{f}$ : Darcy velocity $(\mathrm{m} / \mathrm{s})$.

\section{Greek symbols}

$\alpha_{\mathrm{L}}$ : longitudinal thermal dispersivity $(\mathrm{m}) ; \alpha_{\mathrm{T}}$ : transversal thermal dispersivity $(\mathrm{m})$.

\section{Subscripts}

a: after; b: before; GWHP: groundwater heat pump; hGSHP: horizontal ground source heat pump; LA: Lower Aquifer; RF: Rintheimer Feld; UA: Upper Aquifer; UA + LA: combined Upper and Lower Aquifer; vGSHP: vertical ground source heat pump.

Authors' contributions

CT acquired and analysed the data as well as wrote the manuscript. KM, PBI and PBa provided scientific supervision and guidance for the research. All authors read and approved the final manuscript.

\section{Author details}

${ }^{1}$ Institute of Applied Geosciences (AGW), Karlsruhe Institute of Technology (KIT), Kaiserstraße 12, 76131 Karlsruhe, Germany. ${ }^{2}$ Institute for New Energy Systems (InES), Ingolstadt University of Applied Sciences, Esplanade 10, 85049 Ingolstadt, Germany.

\section{Acknowledgements}

The authors thank Marcus Albert from the local authority real estate office in Karlsruhe for providing the real estate data of the "Rintheimer Feld".

\section{Competing interests}

The authors declare that they have no competing interests.

\section{Availability of data and materials}

All data generated or analysed during this study are included in this published article. The thermal plume code bases on the excel spreadsheet provided by the Ministry of the Environment, Climate Protection and the Energy Sector BadenWürttemberg: https://um.baden-wuerttemberg.de/fileadmin/redaktion/m-um/intern/Dateien/Dokumente/5_Energie/ Erneuerbare_Energien/Geothermie/2_Berechnungsprogramm_GWP_SF_0905.xls.

\section{Funding}

CT is grateful to the funding received through GRACE, the Graduate School for PhD students of the KIT-Center Climate and Environment at the Karlsruhe Institute of Technology (KIT). The work has been supported by the German Research Foundation (Project No. B2850/3-1).

\section{Publisher's Note}

Springer Nature remains neutral with regard to jurisdictional claims in published maps and institutional affiliations.

Received: 18 October 2018 Accepted: 6 March 2019

Published online: 23 March 2019

\section{References}

Alcaraz M, Vives L, Vázquez-Suñé E. The T-I-G ER method: a graphical alternative to support the design and management of shallow geothermal energy exploitations at the metropolitan scale. Renew Energy. 2017;109:213-21. https://doi.org/10.1016/j.renene.2017.03.022. 
Baden-Württemberg. Leitfaden zur Nutzung von Erdwärme mit Erdwärmesonden. Technical report, Umweltministerium Baden-Württemberg, Stuttgart. 2005. http://www.kea-bw.de/fileadmin/user_upload/pdf/Leitfaden_Erdwaerme.pdf. Accessed 11 July 2017.

Baden-Württemberg. Leitfaden zur Nutzung von Erdwärme mit Erdwärmekollektoren. Technical report, Umweltministerium Baden-Württemberg, Stuttgart. 2008. http://www.biberach.de/fileadmin/Formulare/Wasserwirtschaftsamt/ Leitfaeden_Waermepumpen/Leitfaden_Erdwaermekollektoren_Stand_2008_k.pdf. Accessed 18 Jan 2018.

Baden-Württemberg. Arbeitshilfe zum Leitfaden zur Nutzung von Erdwärme mit Grundwasserwärmepumpen. Technical report, Umweltministerium Baden-Württemberg, Stuttgart. 2009a. https://um.baden-wuerttemberg.de/fileadmin/ redaktion/m-um/intern/Dateien/Dokumente/5_Energie/Erneuerbare_Energien/Geothermie/4_Arbeitshilfe_zum_ Leitfaden.pdf. Accessed 28 June 2017.

Baden-Württemberg. Leitfaden zur Nutzung von Erdwärme mit Grundwasserwärmepumpen. Technical report, Umweltministerium Baden-Württemberg, Stuttgart. 2009b. http://www.biberach.de/fileadmin/Formulare/Wasserwirtschaf tsamt/Leitfaeden_Waermepumpen/Leitfaden_Erdwaerme_Grundwasserwaermepumpen_Stand_Okt_2009.pdf. Accessed 28 June 2017.

Bayer P, Saner D, Bolay S, Rybach L. Greenhouse gas emission savings of ground source heat pump systems in Europe: a review. Renew Sustain Energy Rev. 2012;16(2):1256-67. https://doi.org/10.1016/j.rser.2011.09.027.

Bayer P, de Paly M, Beck M. Strategic optimization of borehole heat exchanger field for seasonal geothermal heating and cooling. Appl Energy. 2014;136:445-53. https://doi.org/10.1016/j.apenergy.2014.09.029.

BBergG: Bundesberggesetz Vom 13. August 1980 (BGBI. I S. 1310), Das Zuletzt Durch Artikel 2 Absatz 4 des Gesetzes Vom 20. Juli 2017 (BGBI. I S. 2808) geändert worden ist, 2017. https://www.gesetze-im-internet.de/bbergg/BBergG.pdf. Accessed 19 Apr 04.

Beims U. Planung, Durchführung und Auswertung von Gütepumpversuchen. Zeitschrift für Angewandte Geologie. 1983;29(10):482-90.

Benz SA, Bayer P, Menberg K, Jung S, Blum P. Spatial resolution of anthropogenic heat fluxes into urban aquifers. Sci Total Environ. 2015;524-525:427-39. https://doi.org/10.1016/j.scitotenv.2015.04.003.

Bertermann D, Klug H, Morper-Busch L, Bialas C. Modelling vSGPs (very shallow geothermal potentials) in selected CSAs (case study areas). Energy. 2014;71:226-44. https://doi.org/10.1016/j.energy.2014.04.054.

Bertermann D, Klug H, Morper-Busch L. A pan-European planning basis for estimating the very shallow geothermal energy potentials. Renew Energy. 2015;75:335-47.

Bezelgues-Courtade S, Martin J-C, Schomburgk S, Monnot P, Nguyen D, Le Brun M, Desplan A, et al. Geothermal potential of shallow aquifers: decision-aid tool for heat-pump installation. In: World geothermal congress 2010. 2010. p. 9. https://hal-brgm.archives-ouvertes.fr/docs/00/49/50/43/PDF/Atlas.pdf. Accessed 25 July 2017.

Blum P, Campillo G, Kölbel T. Techno-economic and spatial analysis of vertical ground source heat pump systems in Germany. Energy. 2011;36(5):3002-11. https://doi.org/10.1016/j.energy.2011.02.044.

BMWi: Energiedaten: Gesamtausgabe-Stand: Oktober 2017. Technical report, Bundesministerium für Wirtschaft und Energie, Berlin. 2018. www.bmwi.de/Redaktion/DE/Artikel/Energie/energiedaten-gesamtausgabe.html. Accessed 05 Mar 2018.

Busch K-F, Luckner L, Tiemer K. Geohydraulik. 2nd ed. Stuttgart: Enke; 1974.

Casasso A. Efficiency of closed loop geothermal heat pumps: a sensitivity analysis. Renew Energy. 2014;62:737-46. https ://doi.org/10.1016/j.renene.2013.08.019.

Casasso A, Sethi R. G.POT: a quantitative method for the assessment and mapping of the shallow geothermal potential. Energy. 2016;106(Supplement C):765-73. https://doi.org/10.1016/j.energy.2016.03.091.

De Carli M, Galgaro A, Pasqualetto M, Zarrella A. Energetic and economic aspects of a heating and cooling district in a mild climate based on closed loop ground source heat pump. Appl Therm Eng. 2014;71(2):895-904. https://doi. org/10.1016/j.applthermaleng.2014.01.064.

Eicker U, Pesch R, Thumm F, Dalibard A. Geothermal energy use for heating and cooling of a low energy building. In: Proceedings of IX international scientific and technical conference on new building technologies and design problems, 20-21, vol. 10; 2011.

Epting J, Huggenberger P. Unraveling the heat island effect observed in urban groundwater bodies—definition of a potential natural state. J Hydrol. 2013;501:193-204. https://doi.org/10.1016/j.jhydrol.2013.08.002.

Epting J, Händel F, Huggenberger P. Thermal management of an unconsolidated shallow urban groundwater body. Hydrol Earth Syst Sci. 2013;17(5):1851-69. https://doi.org/10.5194/hess-17-1851-2013.

Epting J, Müller MH, Genske D. Relating groundwater heat-potential to city-scale heat-demand: a theoretical consideration for urban groundwater resource management. Appl Energy. 2018;228:1499-505. https://doi.org/10.1016/j. apenergy.2018.06.154.

Erol S. Estimation of heat extraction rates of GSHP systems under different hydrogelogical conditions. Masterarbeit, Universität Tübingen, Tübingen; 2011.

Galgaro A, Di Sipio E, Teza G, Destro E, De Carli M, Chiesa S, Zarrella A, Emmi G, Manzella A. Empirical modeling of maps of geo-exchange potential for shallow geothermal energy at regional scale. Geothermics. 2015;57:173-84. https://doi. org/10.1016/j.geothermics.2015.06.017.

García-Gil A, Vázquez-Suñe E, Alcaraz MM, Juan AS, Sánchez-Navarro JA, Montlleó M, Rodríguez G, Lao J. GIS-supported mapping of low-temperature geothermal potential taking groundwater flow into account. Renew Energy. 2015;77(Supplement C):268-78. https://doi.org/10.1016/j.renene.2014.11.096.

Gemelli A, Mancini A. GIS-based energy-economic model of low temperature geothermal resources: a case study in the Italian Marche region. Renew Energy. 2011;36(9):2474-83. https://doi.org/10.1016/j.renene.2011.02.014.

Götzl G, Ostermann V, Kalasek R, Heimrath R, Steckler P, Zottl A, Novak A, Haindlmaier G, Hackl R, Shadlau S, Reitner H. GEO-Pot: Seichtes Geothermie Potenzial Osterreichs. Überregionale, interdisziplinäre Potenzialstudie zur Erhebung und Darstellung des oberflächennahen geothermischen Anwendungspotenzials auf Grundlage eines regelmäßigen Bearbeitungsrasters. Osterr Wasser- Abfallw, vol. 5-6. 2010. Accessed 12 Feb 2018.

Hähnlein S, Bayer P, Blum P. International legal status of the use of shallow geothermal energy. Renew Sustain Energy Rev. 2010;14(9):2611-25. https://doi.org/10.1016/j.rser.2010.07.069. 
Hähnlein S, Blum P, Bayer P. Oberflächennahe Geothermie - aktuelle rechtliche Situation in Deutschland. Grundwasser. 2011;16(2):69-75. https://doi.org/10.1007/s00767-011-0162-0.

Hölting B, Coldewey WG. Hydrogeologie: Einführung in die Allgemeine und Angwandte Hydrogeologie. Heidelberg: Spektrum Akademischer Verlag; 2013. https://doi.org/10.1007/978-3-8274-2354-2. http://link.springer. com/10.1007/978-3-8274-2354-2. Accessed 26 July 2017.

Jank R. Integrales Quartiers-Energiekonzept Karlsruhe-Rintheim: Optimierungsmethoden, Praxiserfahrungen mit technischen Innovationen, Umsetzungsergebnisse. Technical report, Volkswohnung Karlsruhe GmbH. 2013. https://doi. org/10.2314/GBV:790783096. https://www.tib.eu/de/suchen/id/TIBKAT\%3A790783096/.

Jank R, Kuklinski R. Integrales Quartiers-Energiekonzept Karlsruhe-Rintheim: Optimierungsmethoden ; Praxiserfahrungen ; Ergebnisse. Fraunhofer-IRB-Verl., Stuttgart; 2015. OCLC: 908616795.

Keim B, Lang U. Thermische Nutzung von Grundwasser durch Wärmepumpen. Technical report, Umweltministerium Baden-Württemberg, Stuttgart. 2008. https://um.baden-wuerttemberg.de/fileadmin/redaktion/m-um/intern/Datei en/Dokumente/5_Energie/Erneuerbare_Energien/Geothermie/5_Prinzipstudie_zur_Berechnung_von_Temperatur feldern.pdf. Accessed 16 Jan 2018.

Kinzelbach W. Numerische Methoden zur Modellierung des Transports Von Schadstoffen Im Grundwasser. München: Oldenbourg Verlag; 1992.

Krämer E. Bohrungen für Erdwärmesonden mit Hohlbohrschnecken. bbr- Leitungsbau Brunnenbau Geothermie H5. 2010. p. 24-7.

Kübert M, Walker-Hertkorn S, Schreyer D, Eyth E. Geothermie. Oberflächennahe. Geothermie SONDERHEFT Aufschlussbohrungen. Grundwassermessstellen. Brunnenbau. Brunnensanierung.pdf. bbr Fachmagazin für Brunnen- und Leitungsbau. Sonderheft Oberflächennahe Geothermie. 2010. p. 84-90.

Kurevija T, Vulin D, Krapec V. Effect of borehole array geometry and thermal interferences on geothermal heat pump system. Energy Conserv Manag. 2012;60:134-42. https://doi.org/10.1016/j.enconman.2012.02.012.

LGRB. Hydrogeologischer Bau und Aquifereigenschaften der Lockergesteine im Oberrheingraben (Baden-Württemberg). LGRB; 2005 .

LGRB. Informationssystem oberflächennahe Geothermie Baden-Württemberg (ISONG); 2017. http://isong.lgrb-bw.de/. Accessed 19 Apr 2018

Lund JW, Boyd TL. Direct utilization of geothermal energy 2015 worldwide review. Geothermics. 2016;60:66-93. https:// doi.org/10.1016/j.geothermics.2015.11.004

Menberg K, Bayer P, Zosseder K, Rumohr S, Blum P. Subsurface urban heat islands in German cities. Sci Total Environ. 2013;442:123-33. https://doi.org/10.1016/j.scitotenv.2012.10.043.

Miglani S, Orehounig K, Carmeliet J. A methodology to calculate long-term shallow geothermal energy potential for an urban neighbourhood. Energy Build. 2018;159:462-73. https://doi.org/10.1016/j.enbuild.2017.10.100.

Molina-Giraldo N. Heat transport modeling in shallow aquifers - the role of thermal dispersion in aquifers and heat conduction into confining layers. Dissertation, Eberhard Karls Universität Tübingen, Tübingen. 2011.

Mueller $\mathrm{MH}$, Huggenberger P, Epting J. Combining monitoring and modelling tools as a basis for city-scale concepts for a sustainable thermal management of urban groundwater resources. Sci Total Environ. 2018;627:1121-36. https://doi. org/10.1016/j.scitotenv.2018.01.250.

Noorollahi Y, Gholami Arjenaki H, Ghasempour R. Thermo-economic modeling and GIS-based spatial data analysis of ground source heat pump systems for regional shallow geothermal mapping. Renew Sustain Energy Rev. 2017;72:648-60. https://doi.org/10.1016/j.rser.2017.01.099.

Ondreka J, Rüsgen MI, Stober I, Czurda K. GIS-supported mapping of shallow geothermal potential of representative areas in south-western Germany_possibilities and limitations. Renew Energy. 2007;32(13):2186-200. https://doi. org/10.1016/j.renene.2006.11.009.

Pahud D. Simulationen Gemessener Erdwärmesondenfelder. 2015.

Pophillat W, Attard G, Bayer P, Hecht-Méndez J, Blum P. Analytical solutions for predicting thermal plumes of groundwater heat pump systems. Renew Energy. 2018; https://doi.org/10.1016/j.renene.2018.07.148.

Pu L, Xu L, Qi D. Structure optimization for horizontal ground heat exchanger. Appl Therm Eng. 2018;136:131-40. https:// doi.org/10.1016/j.applthermaleng.2018.02.101.

Ramming K. Bewertung und Optimierung oberflächennaher Erdwärmekollektoren für verschiedene Lastfälle. Dissertation, Technischen Universität Dresden, Dresden (2007). https://d-nb.info/985908882/34. Accessed 19 Apr 2018.

Rivera JA, Blum P, Bayer P. Ground energy balance for borehole heat exchangers: vertical fluxes, groundwater and storage. Renew Energy. 2015;83:1341-51. https://doi.org/10.1016/j.renene.2015.05.051.

Rivera JA, Blum P, Bayer P. Increased ground temperatures in urban areas: estimation of the technical geothermal potential. Renew Energy. 2017;103:388-400. https://doi.org/10.1016/j.renene.2016.11.005.

Schiel K, Baume O, Caruso G, Leopold U. GIS-based modelling of shallow geothermal energy potential for $\mathrm{CO}_{2}$ emission mitigation in urban areas. Renew Energy. 2016;86:1023-36. https://doi.org/10.1016/j.renene.2015.09.017.

Self SJ, Reddy BV, Rosen MA. Geothermal heat pump systems: status review and comparison with other heating options. Appl Energy. 2013;101:341-8. https://doi.org/10.1016/j.apenergy.2012.01.048.

Solomon A. Welcome to the steam-powered suburbs. 2017. https://www.citylab.com/environment/2017/11/geothermal -suburbs/545354/. Accessed 06 Mar 2018.

VDI 4640, part 2: Thermische Nutzung des Untergrundes - Erdgekoppelte Wärmepumpenanlagen. Berlin: Beuth Verlag. 2001. http://perinorm-s.redi-bw.de/volltexte/CD22DE01/9197793/9197793.pdf?. Accessed 08 May 2018.

VDI 4640, part 1:Thermische Nutzung des Untergrunds - Grundlagen, Genehmigungen, Umweltaspekte. Berlin: Beuth Verlag. 2010. http://perinorm-s.redi-bw.de/volltexte/CD22DE01/1540489/1540489.pdf?. Accessed 14 Feb 2018.

VDI 4640, part 2: Thermische Nutzung des Untergrunds - Erdgekoppelte Wärmepumpenanlagen. Berlin: Beuth Verlag. 2015. http://perinorm-fr.redi-bw.de/volltexte/CD22DE02/2313926/2313926.pdf?. Accessed 25 Jan 2018.

Wang H, Qi C, Du H, Gu J. Thermal performance of borehole heat exchanger under groundwater flow: a case study from Baoding. Energy Build. 2009;41(12):1368-73. https://doi.org/10.1016/j.enbuild.2009.08.001. 
Wirsing G, Luz A. Hydrogeologischer Bau und Aquifereigenschaften der Lockergesteine Im Oberrheingraben (BadenWürttemberg). Regierungspräsidium Freiburg, Landesamt für Geologie, Rohstoffe und Bergbau, Freiburg i. Br.; 2007. https://books.google.de/books?id=jyl5YgEACAAJ.

Zhang Y, Soga K, Choudhary R. Shallow geothermal energy application with GSHPs at city scale: study on the city of Westminster. Géotechnique Lett. 2014;4(2):125-31. https://doi.org/10.1680/geolett.13.00061.

Zhu K, Blum P, Ferguson G, Balke K-D, Bayer P. The geothermal potential of urban heat islands. Environ Res Lett. 2010;5:044002. https://doi.org/10.1088/1748-9326/6/1/019501.

Zhu K, Bayer P, Grathwohl P, Blum P. Groundwater temperature evolution in the subsurface urban heat island of Cologne, Germany. Hydrol Process. 2015;29(6):965-78. https://doi.org/10.1002/hyp.10209.

Submit your manuscript to a SpringerOpen ${ }^{\circ}$ journal and benefit from:

- Convenient online submission

- Rigorous peer review

- Open access: articles freely available online

- High visibility within the field

- Retaining the copyright to your article

Submit your next manuscript at $\gg$ springeropen.com 